\title{
TU/e EnNHOUN

\section{Self-assembled InAs quantum dots formed by molecular beam epitaxy at low temperature and postgrowth annealing}

\section{Citation for published version (APA):}

Zhan, H. H., Nötzel, R., Hamhuis, G. J., Eijkemans, T. J., \& Wolter, J. H. (2003). Self-assembled InAs quantum dots formed by molecular beam epitaxy at low temperature and postgrowth annealing. Journal of Applied Physics, 93(10), 5953-5958. https://doi.org/10.1063/1.1566457

DOI:

10.1063/1.1566457

Document status and date:

Published: 01/01/2003

\section{Document Version:}

Publisher's PDF, also known as Version of Record (includes final page, issue and volume numbers)

\section{Please check the document version of this publication:}

- A submitted manuscript is the version of the article upon submission and before peer-review. There can be important differences between the submitted version and the official published version of record. People interested in the research are advised to contact the author for the final version of the publication, or visit the $\mathrm{DOI}$ to the publisher's website.

- The final author version and the galley proof are versions of the publication after peer review.

- The final published version features the final layout of the paper including the volume, issue and page numbers.

Link to publication

\section{General rights}

Copyright and moral rights for the publications made accessible in the public portal are retained by the authors and/or other copyright owners and it is a condition of accessing publications that users recognise and abide by the legal requirements associated with these rights.

- Users may download and print one copy of any publication from the public portal for the purpose of private study or research.

- You may not further distribute the material or use it for any profit-making activity or commercial gain

- You may freely distribute the URL identifying the publication in the public portal.

If the publication is distributed under the terms of Article 25fa of the Dutch Copyright Act, indicated by the "Taverne" license above, please follow below link for the End User Agreement:

www.tue.nl/taverne

Take down policy

If you believe that this document breaches copyright please contact us at:

openaccess@tue.nl

providing details and we will investigate your claim. 


\title{
Self-assembled InAs quantum dots formed by molecular beam epitaxy at low temperature and postgrowth annealing
}

\author{
H. H. Zhan, ${ }^{\text {a) }}$ R. Nötzel, G. J. Hamhuis, T. J. Eijkemans, and J. H. Wolter \\ eiTT / COBRA Inter-University Research Institute, Eindhoven University of Technology, $5600 \mathrm{MB}$ \\ Eindhoven, The Netherlands
}

(Received 18 December 2002; accepted 19 February 2003)

\begin{abstract}
Self-assembled InAs quantum dots are grown at low temperature (LT) by molecular beam epitaxy (MBE) on GaAs substrates. The growth is in situ monitored by reflection high-energy electron diffraction, and ex situ evaluated by atomic force microscopy for the morphological properties, and by high-resolution X-ray diffraction for the structural properties. While two monolayers as-grown LT $\left(250^{\circ} \mathrm{C}\right)$ InAs layers exhibit shallow mounds due to the low adatom migration length at low temperature, well-developed InAs dots are formed after postgrowth annealing above $450^{\circ} \mathrm{C}$. The structural quality of the LT GaAs matrix grown on top and of the embedded InAs dot layer is improved when a $3 \mathrm{~nm} \mathrm{GaAs}$ interlayer is deposited (at $480^{\circ} \mathrm{C}$ ) on the InAs dots and subsequently annealed at $580^{\circ} \mathrm{C}$ before LT GaAs overgrowth. These high structural quality LT-grown InAs dots are considered for applications in high-speed optical modulators and switches operating at low power by combining the high optical nonlinearity of quantum dots with the ultrafast optical response provided by LT growth in MBE. (C) 2003 American Institute of Physics.
\end{abstract}

[DOI: $10.1063 / 1.1566457]$

\section{INTRODUCTION}

Quantum dots are of great interest for both fundamental research and device applications due to their unique optical properties arising from discrete energy levels. ${ }^{1-5}$ When compared to bulk material and quantum wells, the singular energy dependence of the density of states results in strongly enhanced optical nonlinearity due to state filling of the discrete energy levels. In view of applications for low-power optical modulators and switches based on this high optical nonlinearity of quantum dots, additionally the optical response and recovery times are required to be short. Short optical response times can be accomplished in GaAs grown at low temperature (LT) by molecular beam epitaxy (MBE) due to the ultrafast nonradiative carrier recombination associated with the excess As incorporation during growth. ${ }^{6-12}$ Therefore in searching for materials capable of both high optical nonlinearity and fast response, we have studied high temperature (HT) grown self-assembled InAs dots in the Stranski-Krastanov (SK) mode embedded in a LT GaAs matrix. Unfortunately, these dots exhibit rather strong photoluminescence (PL) efficiency, which was also reported in Ref. 13. This questions the presence of sufficient ultrafast nonradiative carrier recombination processes in the dots and, hence, the ultrafast optical response when relying solely on the matrix properties. Therefore we conclude that it is necessary to grow the dots themselves at low substrate temperature. The LT growth of self-assembled InAs dots, however, is

\footnotetext{
a) Author to whom correspondence should be addressed; electronic mail: huahan@hongkong.com
}

highly challenged by the small adatom migration length, hindering the creation of well-developed InAs dots of high structural quality.

In this work, we report our approaches to overcome the difficulties for the realization of high structural quality, welldeveloped self-assembled InAs/GaAs dots at LT by MBE. Indeed, the small adatom migration length at LT results in the formation of a shallow mound-like surface morphology after the deposition of two monolayers (MLs) LT InAs on LT GaAs instead of well-developed InAs dots obtained at higher temperatures in the SK growth mode. Different attempts to enhance the migration length at LT provided similar surface morphology. Only after a postgrowth annealing process of the LT InAs layer above $450^{\circ} \mathrm{C}$, formation of welldeveloped InAs dots of quantum-size dimensions is observed. When this InAs dot layer is overgrown by $200 \mathrm{~nm}$ LT GaAs, however, poor structural quality of the top GaAs matrix is found. We attribute this mainly to dislocations and stress originating from a number of large InAs clusters formed during annealing in addition to the InAs dots. Improved structural quality of the LT GaAs matrix is obtained by depositing a thin GaAs interlayer on top of the InAs dot layer at $480{ }^{\circ} \mathrm{C}$ before LT GaAs overgrowth. The deposition of the HT GaAs interlayer optimizes the surface morphology on top of the InAs dots and leads to dissolution of the large clusters. Perfect structural quality of the LT GaAs matrix and, thus, of the buried InAs dot layer is achieved by an additional annealing step at $580^{\circ} \mathrm{C}$ after deposition of the thin GaAs interlayer, to fully desorb the residual InAs from the clusters.

We performed the growth and characterizations of LT InAs dots not only on GaAs (100) but also on GaAs (311) A and $\mathrm{B}$ substrates for comparison. Despite some differences in 
TABLE I. Sample numbers and corresponding sample structures and basic growth conditions with reference to the figures where the respective RHEED, $\mathrm{AFM}$, and XRD results are presented.

\begin{tabular}{|c|c|c|c|c|}
\hline Sample & Structure & RHEED & AFM & XRD \\
\hline 213 & HT GaAs buffer $\left(500 \mathrm{~nm}, 580^{\circ} \mathrm{C}\right)$ & Fig. 1(a) & & \\
\hline 120 & LT GaAs buffer $\left(500 \mathrm{~nm}, 250^{\circ} \mathrm{C}\right)$ & Fig. 1(b) & & Fig. 3(a) \\
\hline 180 & as-grown LT InAs ( $\left.2 \mathrm{MLs}, 250^{\circ} \mathrm{C}\right)$ & Fig. 1(c) & Fig. 2(a), & \\
\hline 167 & $\begin{array}{l}\text { LT InAs dots }\left(2 \mathrm{MLs}, 250^{\circ} \mathrm{C}\right) \\
\text { formed after first annealing }\left(480^{\circ} \mathrm{C}\right)\end{array}$ & Fig. 1(d) & $\begin{array}{l}\text { Figs. 5(a) and } 5 \\
\text { Fig. 2(b), } \\
\text { Figs. 5(c) and 5(d) }\end{array}$ & Fig. 3(b) \\
\hline 181 & LT InAs dots + LT GaAs $\left(200 \mathrm{~nm}, 250^{\circ} \mathrm{C}\right)$ & & & Fig. 3(c) \\
\hline 232 & LT InAs dots + HT GaAs $\left(3 \mathrm{~nm}, 480{ }^{\circ} \mathrm{C}\right)$ & & Fig. 2(c) & \\
\hline 200 & $\begin{array}{l}\text { LT InAs dots + HT GaAs }\left(3 \mathrm{~nm}, 480^{\circ} \mathrm{C}\right) \\
+ \text { LT GaAs }\left(200 \mathrm{~nm}, 250^{\circ} \mathrm{C}\right)\end{array}$ & & & Fig. 3(d) \\
\hline 231 & $\begin{array}{l}\text { LT InAs dots }+ \text { HT GaAs }\left(3 \mathrm{~nm}, 480^{\circ} \mathrm{C}\right) \\
+ \text { second annealing }\left(580^{\circ} \mathrm{C}\right)\end{array}$ & & Fig. 2(d) & \\
\hline 207 & $\begin{array}{c}\text { LT InAs dots }+ \text { HT GaAs }\left(3 \mathrm{~nm}, 480{ }^{\circ} \mathrm{C}\right) \\
+ \text { second annealing }\left(580^{\circ} \mathrm{C}\right)+\operatorname{GaAs}\left(200 \mathrm{~nm}, 250{ }^{\circ} \mathrm{C}\right)\end{array}$ & & & Fig. 3(e) \\
\hline 171 & HT InAs dots $\left(2 \mathrm{MLs}, 480^{\circ} \mathrm{C}\right)$ & & & \\
\hline 134 & LT InAs $\left(2 \mathrm{MLs}, 250^{\circ} \mathrm{C}\right)$ on annealed LT GaAs buffer & & Fig. 4(a) & \\
\hline 138 & LT InAs $\left(2 \mathrm{MLs}, 250^{\circ} \mathrm{C}\right)$ on annealed LT GaAs buffer by LGR & & Fig. 4(b) & \\
\hline 143 & $\begin{array}{c}\text { LT InAs }\left(2 \mathrm{MLs}, 250^{\circ} \mathrm{C}\right) \text { on annealed LT GaAs buffer by } \\
\text { MEE }\end{array}$ & & Fig. 4(c) & \\
\hline
\end{tabular}

size and density of the dots, the results for the different substrate orientations are qualitatively similar. Therefore in Sec. II of this article, we focus extensively on the results obtained on GaAs (100), including the PL properties. In Sec. III we address alternative attempts to overcome the low adatom migration length at LT, together with the description of the results for GaAs (311) A and B substrates which underline the necessity of the annealing process for the formation of well-developed InAs dots. Finally, in Sec. IV the article is concluded.

\section{FORMATION OF LT InAs DOTS ON GaAs(100)}

\section{A. Experimental details}

The samples were grown by solid-source MBE at temperatures between 250 and $580^{\circ} \mathrm{C}$ for the different layers and annealing steps. The growth rates of GaAs and InAs were 0.15 and $0.04 \mathrm{~nm} / \mathrm{s}$, respectively, with the $\mathrm{As}_{4}$ beam equivalent pressure of $1.0 \times 10^{-5}$ Torr. The layer sequences in the different experiments and growth conditions are summarized in Table I, second column, with the first column listing the sample numbers. The surface morphology of the GaAs and InAs layers was in situ monitored by reflection high-energy electron diffraction (RHEED), and ex situ characterized by atomic force microscopy (AFM) in air. The structural quality was assessed by high-resolution x-ray diffraction (XRD) ${ }^{14,15}$ For clarity, the third, fourth, and fifth columns of Table I refer to the figures where the respective results are presented.

\section{B. Realization of LT InAs dots by postgrowth annealing}

For the growth of LT InAs dots, first a $500 \mathrm{~nm} \mathrm{HT}$ $\left(580^{\circ} \mathrm{C}\right.$ ) $\mathrm{GaAs}$ buffer layer (sample 213 ) followed by a 500 $\mathrm{nm}$ LT $\left(250^{\circ} \mathrm{C}\right) \mathrm{GaAs}$ bottom layer is grown (sample 120). The corresponding streaky $(2 \times 4)$ and $(1 \times 1)$ RHEED patterns viewed along the [011] direction are depicted in Figs. 1(a) and 1(b) to confirm the high structural quality of the GaAs surfaces before InAs deposition. Two MLs LT InAs are then directly grown on the LT GaAs bottom layer at $250{ }^{\circ} \mathrm{C}$ (sample 180). The RHEED pattern of the LT InAs layer is shown in Fig. 1(c). The distinct intensity modulation of the streaks along their length indicates the formation of a shallow modulated surface morphology. This is confirmed by the AFM image in Fig. 2(a), revealing a mound-like surface structure with average height of the mounds of $0.6 \mathrm{~nm}$, lateral dimensions of $10 \mathrm{~nm} \times 30 \mathrm{~nm} \pm 25 \%$ elongated in the [01-1] direction, and density of $1.6 \times 10^{12} \mathrm{~cm}^{-2}$, clearly evidencing the influence of the small, anisotropic adatom migration length. When grown at $480{ }^{\circ} \mathrm{C}$, two MLs InAs (sample 171) on LT GaAs develop typical SK dots. The morphological characteristics of the InAs layers discussed here are listed comprehensively in Table II. The sample numbers are provided for an easy link to the sample structures and growth conditions summarized in Table I.
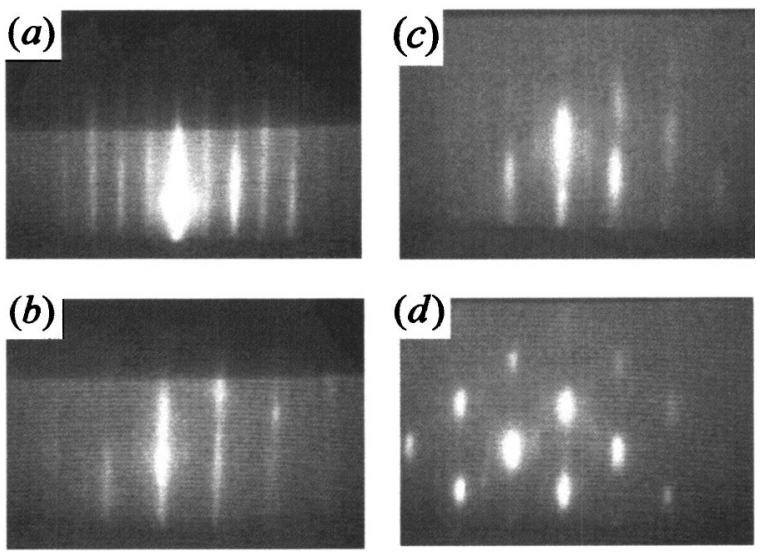

FIG. 1. RHEED patterns viewed along the [110] direction of (a) the HT $\left(580^{\circ} \mathrm{C}\right) \mathrm{GaAs}$ buffer layer, (b) the LT $\left(250^{\circ} \mathrm{C}\right) \mathrm{GaAs}$ bottom layer, (c) the LT InAs layer, and (d) the LT InAs layer after postgrowth annealing at $480{ }^{\circ} \mathrm{C}$ on GaAs (100) substrate. 

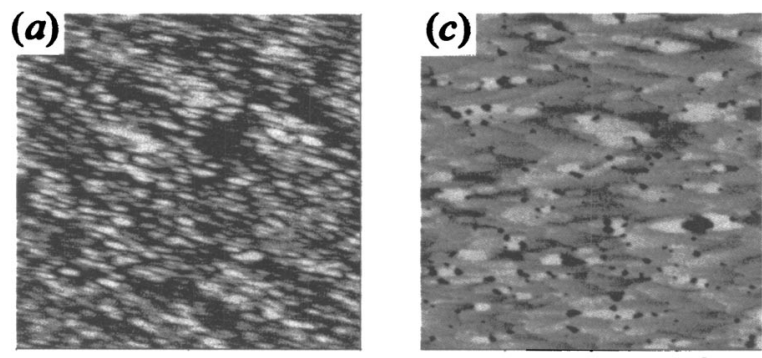

$100 \mathrm{~nm}$
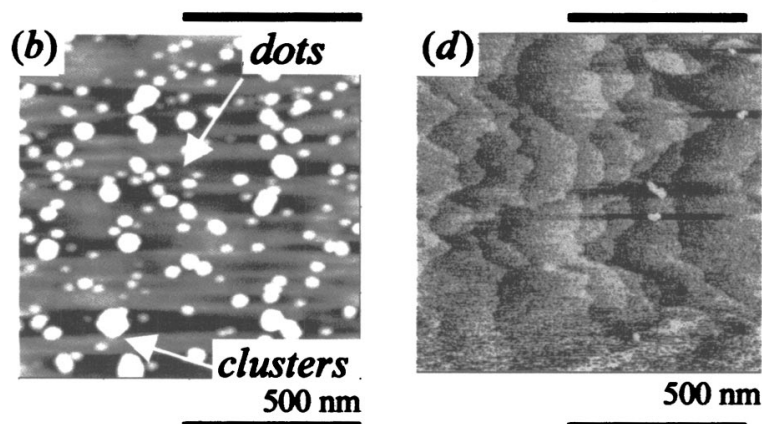

FIG. 2. AFM images of (a) the as-grown LT $\left(250^{\circ} \mathrm{C}\right)$ InAs layer (blackto-white height contrast $1 \mathrm{~nm}$ ), (b) the LT InAs layer after postgrowth annealing at $480{ }^{\circ} \mathrm{C}$ (height contrast $10 \mathrm{~nm}$ ), (c) the LT InAs layer after postgrowth annealing at $480{ }^{\circ} \mathrm{C}$ plus $3 \mathrm{~nm} \mathrm{GaAs}$ (height contrast $2 \mathrm{~nm}$ ), and (d) the LT InAs layer after postgrowth annealing at $480^{\circ} \mathrm{C}$ plus $3 \mathrm{~nm}$ GaAs and second annealing step at $580^{\circ} \mathrm{C}$ (height contrast $1 \mathrm{~nm}$ ) on GaAs (100) substrate.

Well-developed InAs dots are formed when the samples are annealed to $480^{\circ} \mathrm{C}$ after deposition of the two MLs LTgrown InAs layers (sample 167). The RHEED pattern gradually changes from streaky to spotty when the substrate temperature reaches $450{ }^{\circ} \mathrm{C}$. Thereafter the RHEED pattern remains almost unchanged during further annealing up to $480^{\circ} \mathrm{C}$ [Fig. 1(d)]. The AFM image in Fig. 2(b) of the InAs layer after annealing reveals the InAs dots well separated and randomly distributed with strongly increased average height of $2.2 \mathrm{~nm}$, lateral dimensions of $30 \mathrm{~nm} \times 50 \mathrm{~nm} \pm 30 \%$, and lower density compared to that of the mounds. In addition to the InAs dots a number of large clusters with average height

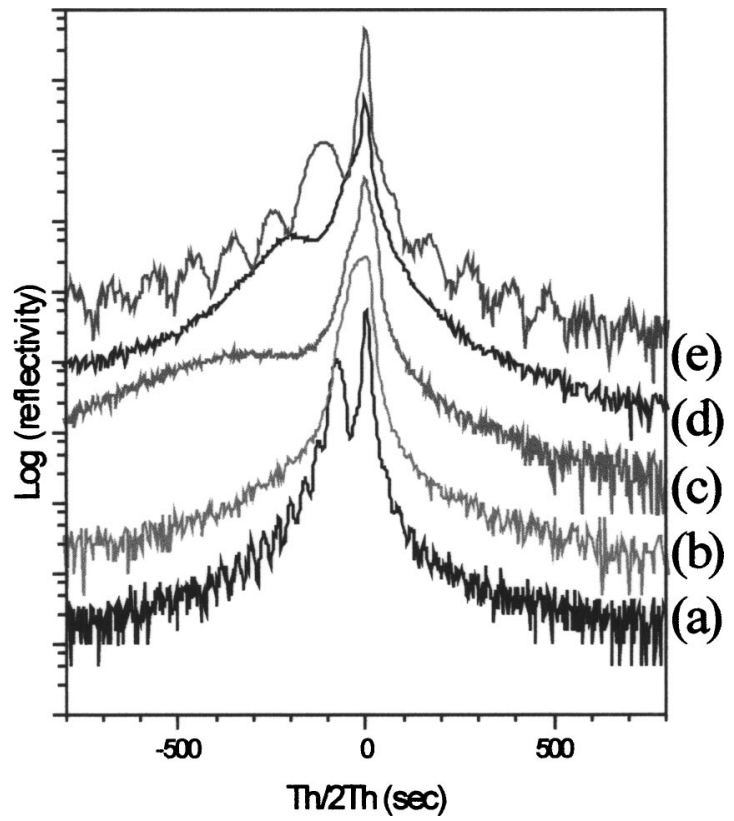

FIG. 3. XRD spectra of the samples with (a) the LT $\left(250^{\circ} \mathrm{C}\right) \mathrm{GaAs}$ bottom layer, (b) the LT GaAs bottom layer after annealing at $480^{\circ} \mathrm{C}$, (c) the LT GaAs bottom layer plus LT InAs layer after annealing at $480^{\circ} \mathrm{C}$ overgrown by $200 \mathrm{~nm}$ LT GaAs, (d) the LT GaAs bottom layer plus LT InAs layer after annealing at $480{ }^{\circ} \mathrm{C}$ plus a $3 \mathrm{~nm}$ GaAs interlayer overgrown by $200 \mathrm{~nm} \mathrm{LT}$ GaAs, and (e) the LT GaAs bottom layer plus LT InAs layer after annealing at $480{ }^{\circ} \mathrm{C}$ plus a $3 \mathrm{~nm} \mathrm{GaAs}$ interlayer and second annealing step at $580{ }^{\circ} \mathrm{C}$ overgrown by $200 \mathrm{~nm} \mathrm{LT} \mathrm{GaAs}$ on GaAs (100) substrate.

of $5.0 \mathrm{~nm}$ and lateral dimensions of $80 \mathrm{~nm} \times 80 \mathrm{~nm} \pm 25 \%$ are formed during the annealing process. Compared to the two MLs InAs SK dots formed at $480{ }^{\circ} \mathrm{C}$ (sample 171) with an average height of $4.4 \mathrm{~nm}$ and lateral dimensions of 25 $\mathrm{nm} \times 25 \mathrm{~nm} \pm 25 \%$, the height of the LT InAs dots after annealing is about $50 \%$ smaller and also their density is lower which is attributed to the postgrowth dot formation by thermally activated, strain driven lateral mass transport out of the almost flat shallow mound-like LT InAs layer. Estimating the total amount of InAs in the dots and clusters suggests the presence of a thin quasi-two-dimensional InAs

TABLE II. Morphological characteristics of the InAs dots, mounds, and clusters in the different experiments (sample numbers) deduced from AFM, including density, height, elongation, and lateral dimensions.

\begin{tabular}{|c|c|c|c|c|c|c|c|c|}
\hline \multirow[b]{2}{*}{ Sample } & \multirow[b]{2}{*}{ Substrate } & \multicolumn{4}{|c|}{ Dots/mounds } & \multicolumn{3}{|c|}{ Large clusters } \\
\hline & & $\begin{array}{l}\text { Density } \\
\left(\mathrm{cm}^{-2}\right)\end{array}$ & $\begin{array}{l}\text { Height } \\
(\mathrm{nm})\end{array}$ & $\begin{array}{c}\text { Dimension } \\
(\mathrm{nm} \times \mathrm{nm})\end{array}$ & Elongation & $\begin{array}{l}\text { Density } \\
\left(\mathrm{cm}^{-2}\right)\end{array}$ & $\begin{array}{l}\text { Height } \\
(\mathrm{nm})\end{array}$ & $\begin{array}{l}\text { Dimension } \\
(\mathrm{nm} \times \mathrm{nm})\end{array}$ \\
\hline \multirow[t]{3}{*}{180} & $(100)$ & $1.6 \times 10^{12}$ & 0.6 & $10 \times 30 \pm 25 \%$ & {$[01-1]$} & & & \\
\hline & (311)A & $3.2 \times 10^{10}$ & 0.6 & $30 \times 100 \pm 30 \%$ & {$[-233]$} & & & \\
\hline & (311)B & $3.2 \times 10^{10}$ & 0.6 & $20 \times 80 \pm 40 \%$ & {$[-233]$} & & & \\
\hline 134 & (100) & $9.6 \times 10^{10}$ & 0.6 & $30 \times 50 \pm 35 \%$ & {$[01-1]$} & & & \\
\hline 138 & (100) & $1.6 \times 10^{11}$ & 0.3 & $15 \times 50 \pm 40 \%$ & [01-1] & & & \\
\hline 143 & (100) & $1.2 \times 10^{11}$ & 0.3 & $30 \times 40 \pm 40 \%$ & {$[01-1]$} & & & \\
\hline \multirow[t]{3}{*}{167} & $(100)$ & $1.5 \times 10^{10}$ & 2.2 & $30 \times 50 \pm 30 \%$ & & $4.0 \times 10^{9}$ & 5.0 & $80 \times 80 \pm 25 \%$ \\
\hline & (311)A & $6.0 \times 10^{9}$ & 1.2 & $40 \times 40 \pm 30 \%$ & & $2.5 \times 10^{9}$ & 5.0 & $90 \times 90 \pm 30 \%$ \\
\hline & (311)B & $1.2 \times 10^{10}$ & 1.0 & $25 \times 40 \pm 20 \%$ & {$[-233]$} & $1.0 \times 10^{9}$ & 5.0 & $60 \times 100 \pm 40 \%$ \\
\hline \multirow[t]{3}{*}{171} & $(100)$ & $8.0 \times 10^{10}$ & 4.4 & $25 \times 25 \pm 25 \%$ & & $7.0 \times 10^{8}$ & 5.0 & $60 \times 60 \pm 15 \%$ \\
\hline & (311)A & $9.0 \times 10^{10}$ & 1.5 & $15 \times 25 \pm 25 \%$ & & $4.3 \times 10^{9}$ & 2.5 & $45 \times 45 \pm 30 \%$ \\
\hline & (311)B & $1.6 \times 10^{10}$ & 1.5 & $20 \times 30 \pm 30 \%$ & {$[-233]$} & $4.0 \times 10^{9}$ & 2.5 & $40 \times 60 \pm 25 \%$ \\
\hline
\end{tabular}


layer beneath the dots after annealing at $480^{\circ} \mathrm{C}$ similar to the two-dimensional wetting layer in the SK growth mode.

\section{Realization of high structural quality buried LT InAs dots in a LT GaAs matrix}

After the formation of LT InAs dot structures by postgrowth annealing, the most important step is to incorporate the dots in a LT GaAs matrix maintaining high structural quality of both the dot layer and the LT GaAs matrix on top. Again, the surface morphologies are studied by AFM while the crystal quality is deduced from XRD. XRD is performed on the InAs dot layers overgrown by $200 \mathrm{~nm}$ LT GaAs making the measurement sensitive to the structural quality of the LT GaAs matrix as well as the buried InAs dots. For reference, we show in Fig. 3 the XRD spectrum (a) of sample 120 with only the $500 \mathrm{~nm}$ thick LT GaAs bottom layer. Sharp peaks are revealed from the substrate (centered at $0 \mathrm{~s}$ ) and from the LT GaAs layer (centered at $-100 \mathrm{~s}$ ), which is under compressive strain due to the excess As incorporation. In addition, clear Pendellösung fringes are detected, indicating the high structural perfection of the LT GaAs layer and interface. When the LT GaAs bottom layer is annealed at $480^{\circ} \mathrm{C}$, as is done to obtain the formation of the LT InAs dot layer in Fig. 2(b), the XRD spectrum (b) in Fig. 3 reveals a broader peak close to the substrate peak position. This merging of the LT GaAs peak with the substrate peak upon annealing is commonly observed due to As precipitation.

After overgrowth of the InAs dot layer of Fig. 2(b) by $200 \mathrm{~nm}$ LT GaAs, the XRD spectrum (c) in Fig. 3 shows the substrate peak with a close by shoulder on the compressive side from the (annealed) bottom LT GaAs layer and a very broad reflection (centered at around $-400 \mathrm{~s}$ ) which is attributed to the top LT GaAs layer. Hence when directly grown on the annealed InAs dot layer, the top LT GaAs matrix is of poor structural quality, most probably due to the presence of the big clusters introducing strongly inhomogeneous stress and dislocations.

To solve this problem we grow a three nm thin HT GaAs layer at $480^{\circ} \mathrm{C}$ over the annealed InAs dot layer. The important point is that the thickness of the HT GaAs layer of $3 \mathrm{~nm}$ is sufficient to fully bury the InAs dots but to leave the large clusters partly uncovered. After several minutes, the RHEED pattern then changes gradually from spotty back to streaky, indicating the formation of a rather flat surface morphology. The AFM image at this stage shown in Fig. 2(c) (sample 232) confirms that the surface is mostly flat, consisting of small terraces and monolayer high steps, but has a number of holes, of which some are surrounded by shallow mounds. The density of the holes is related to that of the large clusters, indicating that the clusters have dissolved, most probably forming a second wetting layer and that the surface on top of the buried InAs dots is flat. Although some shape changes during capping can also occur for the InAs dots, this is not considered to qualitatively alter their appearance due to the rather low $\left(480^{\circ} \mathrm{C}\right)$ temperature. The XRD spectrum (d) in Fig. 3 of the sample overgrown by $200 \mathrm{~nm}$ LT GaAs shows improved structural quality of the LT GaAs matrix with a narrower peak. The quality is, however, still far off that of the LT GaAs buffer layer.

Perfect structural quality is achieved when the InAs dot layer after annealing at $480{ }^{\circ} \mathrm{C}$ and thin $\mathrm{GaAs}$ capping is further annealed up to $580^{\circ} \mathrm{C}$. Then the residual InAs from the clusters is desorbed, the holes are filled, and the surface consists of extended terraces separated by monolayer high steps as shown in the AFM image in Fig. 2(d) (sample 231). The XRD spectrum (e) in Fig. 3 of the related sample overgrown with $200 \mathrm{~nm}$ LT GaAs now shows a sharp substrate peak (centered at $0 \mathrm{~s}$ ), and a well-resolved peak of the LT GaAs top layer (centered at $-100 \mathrm{~s}$ ). This together with the clear Pendellösung fringes evidences the high structural quality of the LT GaAs top layer and of the interface and, hence, of the buried InAs dots. The broader peak of the LT GaAs top layer compared to that of the LT GaAs bottom layer and the larger periodicity of the Pendellösung fringes are due to the smaller thickness.

PL measurements at $4 \mathrm{~K}$ of these LT grown and annealed InAs dots embedded in the LT GaAs matrix reveal no or close to the detection limit emission. PL excitation was by the $532 \mathrm{~nm}$ line of a Nd:YAG laser with excitation power density up to $400 \mathrm{~W} / \mathrm{cm}^{2}$ and the signal was detected by an InGaAs/InP charge coupled device (CCD) with integration times longer than $30 \mathrm{~s}$ per scan to enhance the sensitivity. This confirms that, despite of the annealing process, highly effective nonradiative carrier recombination channels are present in the LT dots whose structural perfection is comparable to that of InAs dots grown at higher temperatures in the SK mode which usually exhibit high PL efficiency. Only when the samples are annealed at the very end of growth to temperatures up to $600{ }^{\circ} \mathrm{C}$, a weak PL signal can be observed in the typical wavelength range for InAs dots around $1100 \mathrm{~nm}$. Therefore strong optical nonlinearity together with fast response can be expected for our LT InAs dots, finding applications in high-speed and low-power optical modulators and switches, in contrast to light emitting devices employing SK dots.

\section{DIFFERENT ATTEMPTS TO ENHANCE THE SURFACE MIGRATION LENGTH AT LT}

\section{A. Variation of InAs growth conditions on GaAs (100)}

To circumvent the annealing step, different attempts have been carried out to enhance the adatom migration length even at LT. These include (i) LT InAs growth on annealed (at $580{ }^{\circ} \mathrm{C}$ ) LT GaAs buffer layers (sample 134) which exhibit smoother surfaces, (ii) strongly reducing the InAs growth rate to $0.004 \mathrm{~nm} / \mathrm{s}$ (sample 138), and (iii) growth by migration enhanced epitaxy (MEE) (sample 143). The AFM images of the so prepared LT InAs layers are shown in Figs. 4(a)-4(c), respectively. There are only minor differences in the surface morphology with only slightly larger lateral dimensions of the shallow mounds, which might indicate some, but insufficient enhancement of the adatom migration length. Therefore the postgrowth annealing process above $450^{\circ} \mathrm{C}$ is necessary to overcome the low adatom migration length at low temperature for the formation of high quality InAs dots. 

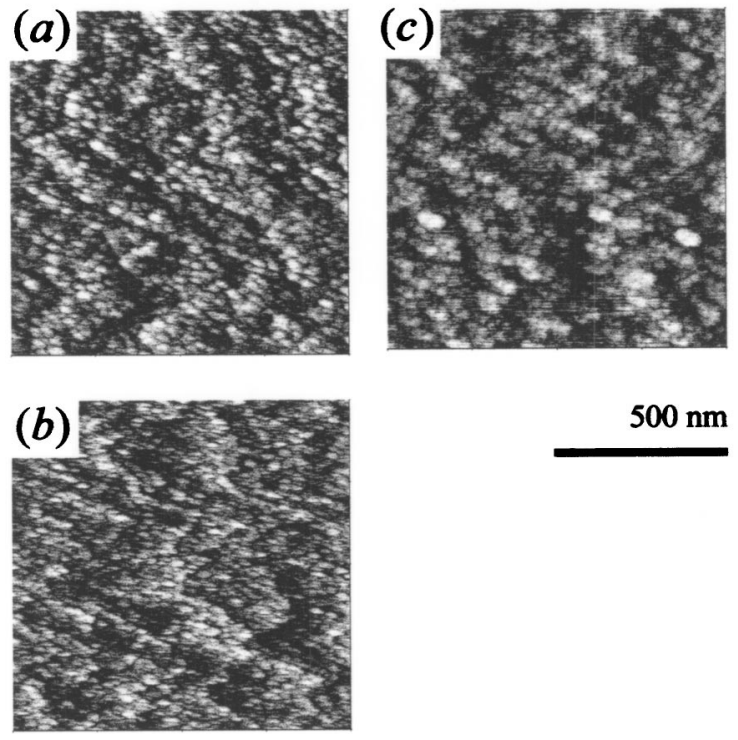

FIG. 4. AFM images of the LT $\left(250^{\circ} \mathrm{C}\right)$ InAs layers as-grown (a) on annealed LT GaAs, (b) on annealed LT GaAs at low growth rate, and (c) on annealed LT GaAs by MEE. The black-to-white height contrast is $1 \mathrm{~nm}$ in all images.

\section{B. LT InAs dot formation on GaAs (311) A and B}

The growth on substrates with different orientation might have influence on the adatom migration length at low temperature and the formation of LT InAs dots due to the altered surface bond configurations. We exemplarily chose the GaAs (311) A and B substrates which lie midway between the (100) and (111) planes. The mound-like surface morphologies in Figs. 2(a), 5(a), and 5(b) of the LT InAs layers on GaAs (100), and GaAs (311) A and B (grown sideby-side in sample 180), however, are rather similar. The av-
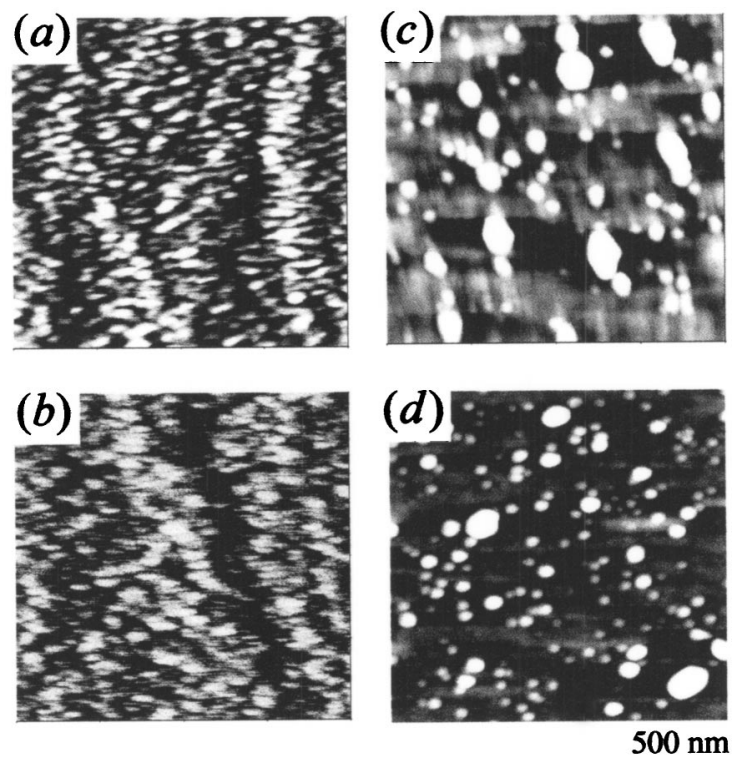

FIG. 5. AFM images of the as-grown LT $\left(250^{\circ} \mathrm{C}\right)$ InAs layers (a) on $\mathrm{GaAs}$ (311)A and (b) on GaAs (311)B substrate (black-to-white height contrast 1 $\mathrm{nm})$. (c) and (d) are the AFM images of the LT InAs layers after annealing at $480{ }^{\circ} \mathrm{C}$ on GaAs (311)A and GaAs (311)B (height contrast $10 \mathrm{~nm}$ ). erage height of the InAs mounds on GaAs (311) A and B of $0.6 \mathrm{~nm}$ is unchanged compared to that on GaAs (100) while the lateral dimensions of $30 \mathrm{~nm} \times 100 \mathrm{~nm} \pm 30 \%$ and 20 $\mathrm{nm} \times 80 \mathrm{~nm} \pm 40 \%$ are somewhat larger with elongation along the $[-233]$ direction.

After postgrowth annealing at $480^{\circ} \mathrm{C}$, well-developed InAs dots are formed on GaAs (311) A and B substrates (sample 167). Compared to the InAs dots on GaAs (100) [Fig. 2(b)], the dots on GaAs (311) A and B are of lower average height and density, but similar average lateral dimensions [Figs. 5(c) and 5(d)]. The number of the large clusters is slightly smaller. Therefore the surface orientation seems to have little effect on the formation of InAs dots during postgrowth annealing. Regarding the steps towards formation of high-quality LT InAs dots embedded in a LT GaAs matrix, i.e., thin GaAs capping, annealing, and LT GaAs overgrowth, despite some morphological differences observed by AFM, the XRD results are very similar to those obtained on GaAs (100).

\section{CONCLUSIONS}

In summary, we have fabricated self-assembled InAs/GaAs quantum dots by molecular beam epitaxy (MBE) growth of $2 \mathrm{MLs}$ InAs at low temperature (LT: $250^{\circ} \mathrm{C}$ ) and postgrowth annealing at $480^{\circ} \mathrm{C}$. Characterization of the structural properties reveals that the mechanism of dot formation is greatly influenced by the low adatom mobility at low temperature which can be overcome by annealing. The realization of high structural quality LT InAs dots buried within a LT GaAs matrix has been achieved by inserting a 3 $\mathrm{nm}$ thin high-temperature grown GaAs interlayer between the InAs dots and the overgrown LT GaAs layer. LT InAs dot formation and GaAs overgrowth behave similar on GaAs (100) and GaAs (311) A and B substrates with minor differences in dot size and density. The absence of photoluminescence from the dots suggests efficient nonradiative carrier recombination. Hence the realization of high structural quality LT-grown InAs dots might find applications in lowpower, ultrafast optical modulators and switches based on the enhanced optical nonlinearity of quantum dots combined with the ultrafast optical response due to nonradiative carrier recombination obtained by $\mathrm{LT}$ growth in MBE.

${ }^{1}$ R. Nötzel, Semicond. Sci. Technol. 11, 1365 (1996).

${ }^{2}$ D. Leonard, M. Krishnamurthy, C. M. Reaves, S. P. Denbars, and P. M. Petroff, Appl. Phys. Lett. 63, 3203 (1993).

${ }^{3}$ Y. Sugiyama, Y. Nakata, S. Muto, Y. Awano, and N. Yokoyama, Physica E (Amsterdam) 7, 503 (2000)

${ }^{4}$ Y. Nakata, K. Mukai, M. Sugawara, K. Ohtsubo, H. Ishikawa, and N. Yokoyama, J. Cryst. Growth 208, 93 (2000).

${ }^{5}$ T. Mano, K. Watanabe, S. Tsukamoto, N. Koguchi, H. Fujioka, M. Oshima, C. Lee, J. Leem, H. J. Lee, and S. K. Noh, Appl. Phys. Lett. 76, 3543 (2000).

${ }^{6}$ D. J. Eaglesham, J. Appl. Phys. 77, 3597 (1995).

${ }^{7}$ G. Apostolopoulos, N. Boukos, A. Travlos, J. Herfort, and K. H. Ploog, Appl. Phys. Lett. 79, 3422 (2001).

${ }^{8}$ D. D. Nolte, M. R. Melloch, S. J. Ralph, and J. M. Woodall, Appl. Phys. Lett. 61, 3098 (1992).

${ }^{9}$ R. Takahashi, Y. Kawamura, and H. Iwamura, Appl. Phys. Lett. 68, 153 (1996). 
${ }^{10}$ M. Haiml, U. Siegner, F. Morier-Genoud, U. Keller, M. Luysberg, P. Specht, and E. R. Weber, Appl. Phys. Lett. 74, 1269 (1999).

${ }^{11}$ H. Tsuda, A. Hirano, R. Takahashi, K. Sato, and K. Hagimoto, Electron. Lett. 32, 365 (1996).

${ }^{12}$ T. Okuno, Y. Masumoto, M. Ito, and H. Okamoto, Appl. Phys. Lett. 77, 58 (2000).
${ }^{13}$ X. D. Wang, Z. C. Niu, H. Wang, and S. L. Feng, J. Cryst. Growth 218, 206 (2000).

${ }^{14}$ A. Krost, F. Heinrichsdorff, D. Bimberg, A. Darhuber, and G. Bauer, Appl. Phys. Lett. 68, 785 (1996).

${ }^{15}$ M. A. Capano, M. Y. Yen, K. G. Eyink, and T. W. Haas, Appl. Phys. Lett. 58, 1854 (1991) 